\title{
Highly bulky and stable geometry-constrained iminopyridines: Synthesis, structure and application in Pd-catalyzed Suzuki coupling of aryl chlorides
}

\author{
Yi Lai ${ }^{1}$, Zhijian Zong ${ }^{1}$, Yujie Tang ${ }^{1}$, Weimin $\mathrm{Mo}^{1}$, Nan Sun ${ }^{1}$, Baoxiang $\mathrm{Hu}^{1}$, \\ Zhenlu Shen ${ }^{1}$, Liqun Jin ${ }^{* 1,2}$, Wen-hua Sun ${ }^{* 3}$ and Xinquan $\mathrm{Hu}^{* 1,2}$
}

\section{Full Research Paper}

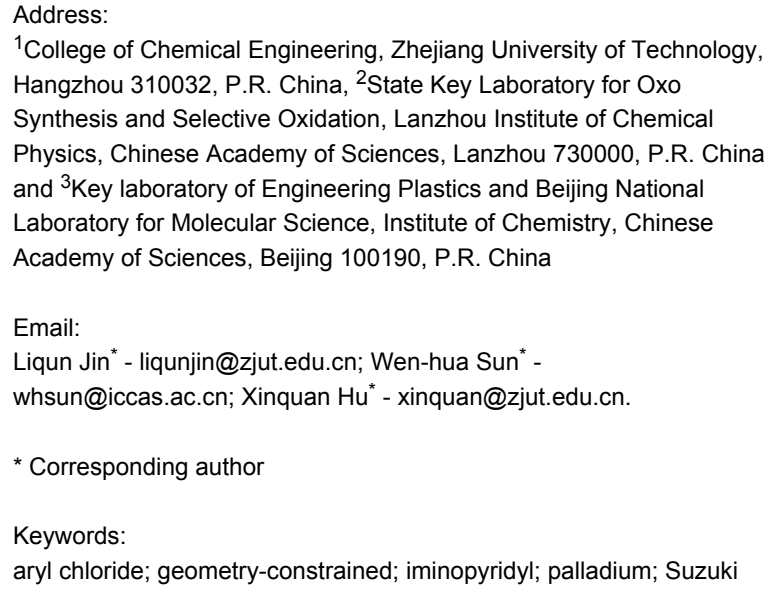

\author{
doi:10.3762/bjoc. 13.24 \\ Received: 21 December 2016 \\ Accepted: 19 January 2017 \\ Published: 03 February 2017 \\ Associate Editor: K. Itami
}

Beilstein J. Org. Chem. 2017, 13, 213-221.

(C) 2017 Lai et al.; licensee Beilstein-Institut.

License and terms: see end of document.

\begin{abstract}
A series of bulky geometry-constrained iminopyridylpalladium chlorides were developed. The steric environment adjacent to the nitrogen atom in the pyridine rings and diimine parts enhanced the thermal stability of the palladium species. Bulkier groups at the imino group stabilized the palladium species and the corresponding palladium chlorides showed high activities in the coupling reaction of aryl chlorides.
\end{abstract}

\section{Introduction}

Palladium-promoted $\mathrm{C}-\mathrm{C}$ coupling reactions are recognized as one of the most powerful tools in organic syntheses, pharmaceutical processes and biological modifications [1-4]. The achievement is largely beneficial to organic chemists for their parallel contributions in Pd-catalyzed transformations as well as for discovering new reactions. The improvement of the efficiency of noble metal catalysts is still highly attractive from both the academic and the industrial point of view [5].
Targeting the handling and applicability of palladium catalysts, various species have been developed through the use of diversified ligands [6-12].

Typical ligands that successfully enhanced the reactivity of palladium species towards the oxidative addition of aryl or alkyl halides include phosphine ligands independently developed by, for example, Buchwald [13-15], Hartwig [16,17], Fu [18-20], 
Kwong [21-23], Tang [24-27] and Lundgren [28], and $\mathrm{N}$-heterocyclic carbene ligands due to the inherent strong sigma-donating property [29]. Alternatively, the palladacycles reported by Herrmann and Beller in the 1990s [30] effectively elongated the lifetime of the active Pd species through employing bidentate or multidentate ligands [31-36]. Meanwhile nitrogen ligands are also widely used for palladium catalysts in coupling reactions with the advantage of convenient synthetic methods, easy functional group modifications and better stability [37-43]. Pyridine, azole and imine-based N( $\left.\mathrm{sp}^{2}\right)$ ligands received considerable attention, especially bidentate $\mathrm{N}, \mathrm{N}$-ligands. In general, most bidentate $\mathrm{N}, \mathrm{N}\left(\mathrm{sp}^{2}\right)$ ligands comprise symmetrical frameworks, such as bipyridine [44-46], biimidazole [47,48], and diimine [49-53]. Moreover iminopyridines were attractive for a more straightforward preparation, the condensation of pyridine-2-carboxaldehyde or ketone and the relevant primary amines. By this work a wide variety of different substituents were introduced leading to a diversity with regard to steric and electronic aspects [54-59].

Recently, we have developed a series of geometry-constrained iminopyridyl compounds [60-64] and their corresponding palladium complexes showed a good catalytic efficiency for both Suzuki and Heck cross-coupling reactions. The favorable effect originated from the ring-fused framework being able to establish a strained environment for better stability. Efficient couplings were achieved with aryl bromides or iodides as substrates, however, it is still not favored for the cheaper and more widely available aryl chloride substrates. For $\mathrm{C}-\mathrm{Cl}$ bond activation, the major efforts have focused on using extraordinarily electron-rich ligands to promote the oxidative addition. We assumed that the coupling of aryl chlorides could also be furnished under high temperature, if the palladium catalyst is stable enough. The formation of palladium black was observed in reactions of aryl chlorides using the reported palladium catalyst system, which inspired us to improve the thermal stability of the palladium complex. The steric environment adjacent to the nitrogen in pyridine rings and diimine parts enhanced the thermal stability of metal species, albeit under harsh conditions [65-68]. Therefore, Figure 1 schematically illustrates various substituents of iminopyridines constraining the geometrical influence around the palladium center. In this report, the modifications using various substituents with different electronic and steric factors have been explored, and fortunately thermally stable palladium chlorides are obtained demonstrating high activities toward the coupling reaction of aryl chlorides.

\section{Results and Discussion}

According to Figure 1, the geometry-constrained iminopyridyl skeleton could be modified at three sites: $C^{\mathrm{a}}, C^{\mathrm{b}}$ and $N^{\mathrm{c}}$. Both the derivation of the $C^{\text {a }}$ position and adjusting the imino part are

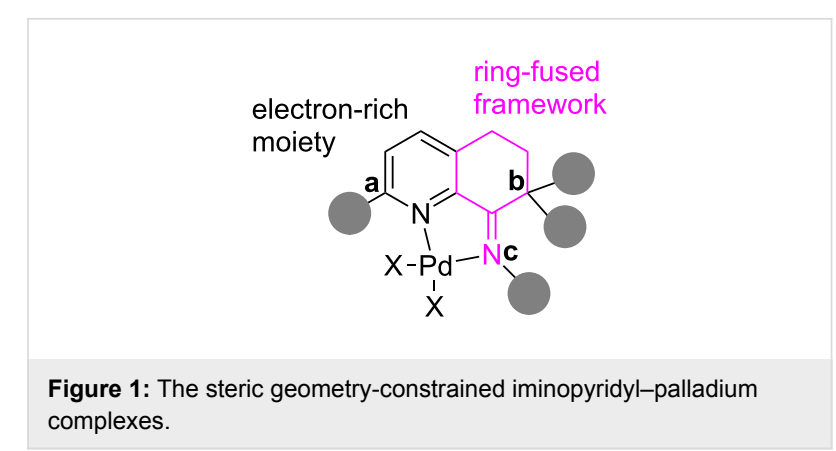

expected to protect the active palladium center from decomposition during the catalytic cycle. Nevertheless, multiple substitutions at $C^{\mathrm{b}}$ probably prohibit any tautomerization and result to increase the stability of iminopyridines and their palladium catalysts.

6,7-Dihydroquinolin-8(5H)-one (1) and 2-chloro-6,7-dihydroquinolin-8 $(5 H)$-one $(2)$ could be prepared in large amounts following the previously reported synthetic procedures [60,62,69-71]. Geminal dimethylation of 1 with $\mathrm{NaH}$ and $\mathrm{MeI}$ in THF afforded 7,7-dimethyl-6,7-dihydroquinolin-8(5H)-one (3) easily in good yield. Meanwhile, the Ni-catalyzed Kumada coupling of 2 with methylmagnesium chloride produced 2-methyl-6,7-dihydroquinolin-8(5H)-one (4) efficiently with quantitative yield. With compounds 1, 2, 3 and 4 in hand, further condensations with different arylamines and direct coordination to $\mathrm{PdCl}_{2}$ in one pot smoothly in the presence of TsOH. For this transformation, we found that vigorous stirring during the reaction was very important, which increased the yields from medium to quantitative results [72]. Following a similar procedure as described in the Experimental section, complexes Pd1 to Pd5 were synthesized and could be isolated by simple work-up (Scheme 1). All of these complexes have been fully characterized and confirmed by NMR and HRMS, and the analyses are in good agreement with that of the previously reported palladium complexes [72]. All of these complexes could be stored open to air without any decomposition for several months except Pd4. Their melting points $\left[>240{ }^{\circ} \mathrm{C}\right]$ indicated their high thermostability, especially $\mathbf{P d} \mathbf{2}$ with a melting point up to $325^{\circ} \mathrm{C}$.

With these sterically hindered iminopyridine-palladium complexes Pd1 to Pd5 in hand, we firstly investigated their catalytic activity directly in Suzuki cross-coupling reactions with chlorobenzene as the electrophile. The reactions were performed under the previously reported conditions without any change except at the higher reaction temperature. As shown in Table 1, using complex Pd1, which has exhibited an impressive efficiency in Pd-catalyzed Suzuki coupling of aryl bromides, only delivered $18 \%$ conversion of chlorobenzene. The 


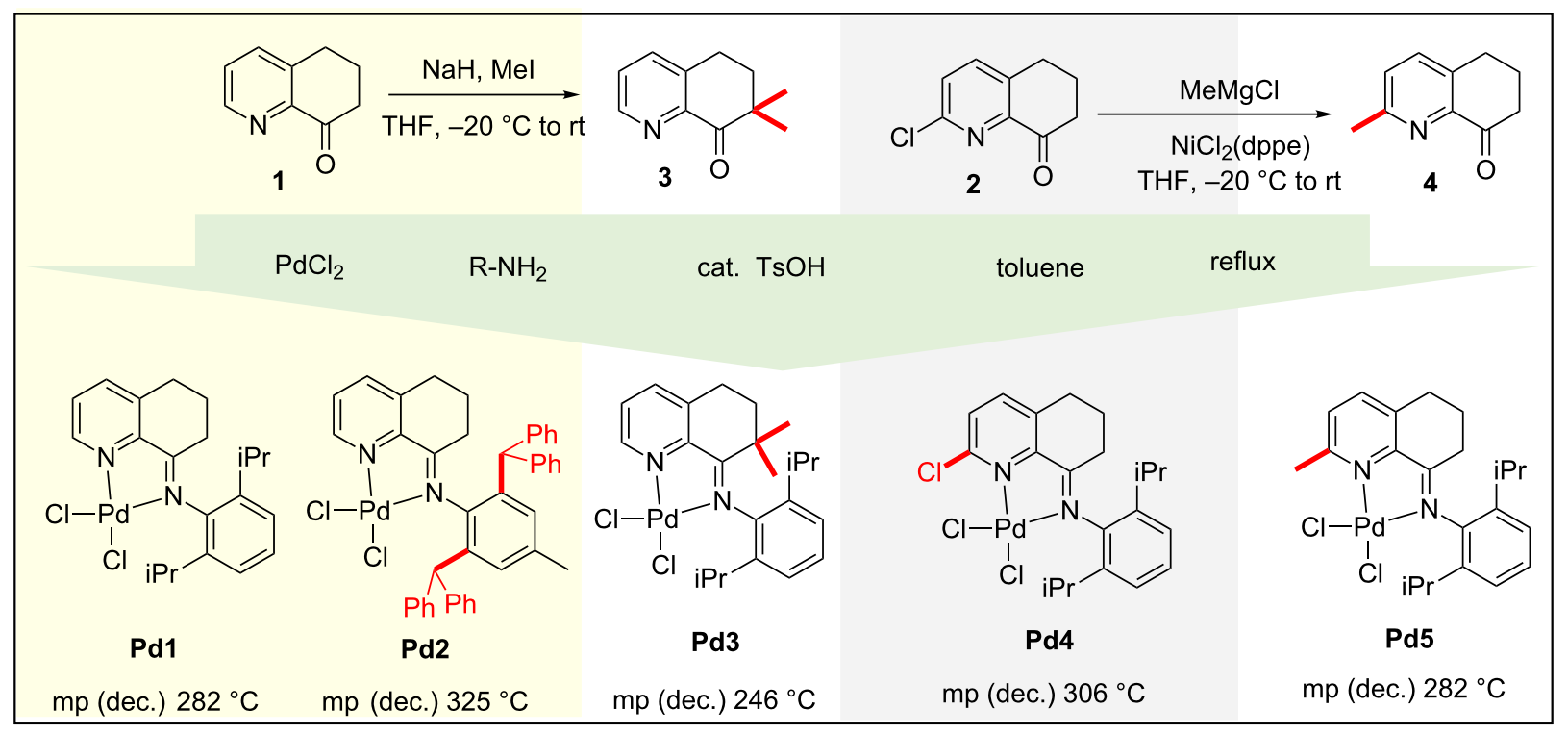

Scheme 1: Preparation of the bulky iminopyridyl-palladium complexes.

modification of the $C^{\mathrm{b}}$ position by importing two methyl groups of Pd1 to Pd3 did not give any improvement while with much lower conversion. The efforts changing the steric and electronic effect from the ortho-position of pyridyl (Pd4 and Pd5) also failed to promote $\mathrm{C}-\mathrm{Cl}$ bond activation. To our delight, complex Pd2, with a bulkier version of dipp (2,6-diisopropylphenyl) in the imino motif, displayed significant enhance with the conversion up to $44 \%$. The results in Table 1 and Figure 1 matched well with our proposal that improving the stability of palladium species favored $\mathrm{C}-\mathrm{Cl}$ bond activation under higher temperature.

Single crystals of complex Pd2 were obtained by slow diffusion of diethyl ether to a saturated dichloromethane solution and the molecular structure in solid state was determined by X-ray diffraction [73]. Presented in Figure 2, the molecular structure and the predicted conformation was unambiguously confirmed. The same as before, the complexes also exhibit square-planar coordination geometry around the palladium centre with a slight distortion. Selected bond lengths and angles listed in Table 2 suggest that both the imino double bond N3-C3 (1.304 $\AA$ ) and Pd-N3 (2.037 $\AA$ ) were slightly longer than that of our previous reported iminopyridyl-palladium complexes (1.27-1.30 $\AA$, 2.02-2.03 $\AA$, respectively) [57]. The structure clearly showed a flexible steric bulky effect from the replacement of two methyl groups of iPr by phenyl rings and the palladium center could be protected very well.

With Pd2 as the catalyst, we then put our efforts on simply optimizing the reaction conditions for the coupling between chlorobenzene and 4-methylphenylboronic acid. We noticed that water could promote the conversion of chlorobenzene to $62 \%$ which might be due to the better solubility of the base in toluene $/ \mathrm{H}_{2} \mathrm{O}$ (2.5:1) mixed solvents (Table 3, entry 1). Bases have been proven to play an important role in Suzuki coupling reactions [74]. Then, in mixed solvents, various bases were ex-

Table 1: Pd-catalyzed coupling of chlorobenzene and 4-tolylboronic acid using Pd1-Pd5 as the catalyst. ${ }^{a}$

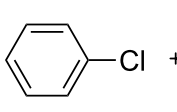

1-1

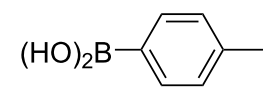

2-1

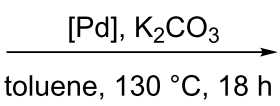

Pd3

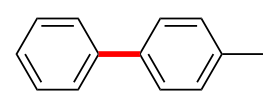

3-1

\begin{tabular}{llllll}
\hline Cat. & Pd1 & Pd2 & Pd3 & Pd4 & Pd5 \\
\hline Conv. $(\%)^{b}$ & 18 & 44 & 5 & 4 & 18 \\
\hline
\end{tabular}

aReaction conditions: chlorobenzene $(1.0 \mathrm{mmol}), 4$-methylphenylboronic acid $(1.2 \mathrm{mmol})$, toluene $(3.0 \mathrm{~mL}), \mathrm{Pd} \mathrm{catalyst}(1 \mathrm{~mol} \%), 18 \mathrm{~h}, \mathrm{purged}$ with $\mathrm{N}_{2}$ for 2 min. ${ }^{b}$ Conversions were determined by GC. 


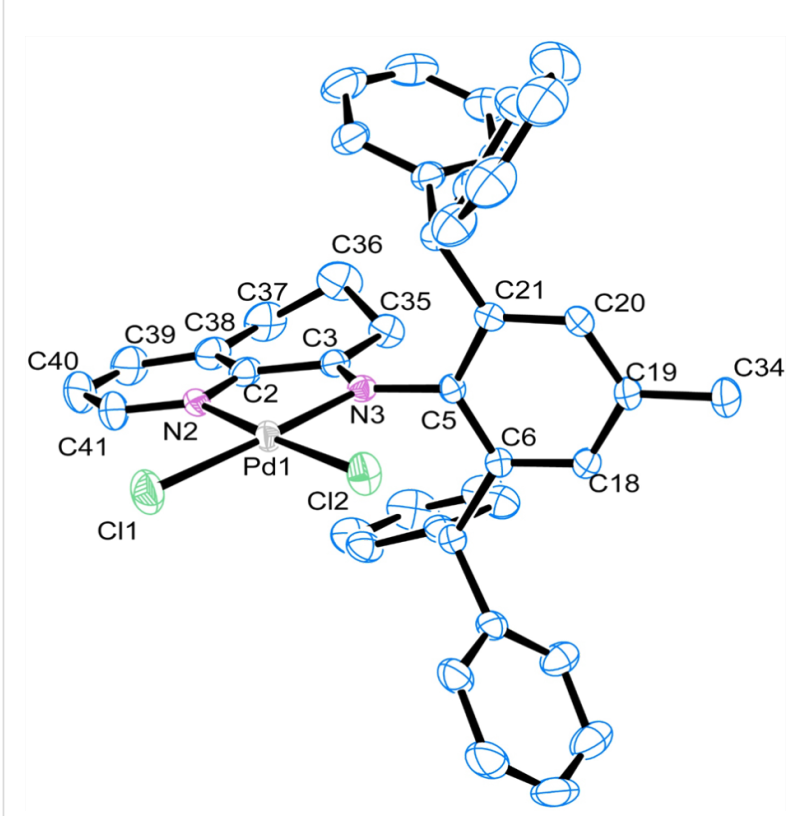

Figure 2: ORTEP drawing of Pd2 with thermal ellipsoids at $30 \%$ probability level. Hydrogen atoms and the solvent $\mathrm{CH}_{2} \mathrm{Cl}_{2}$ have been omitted for clarity.

amined (Table 3, entries 1-10). Compared with $\mathrm{K}_{2} \mathrm{CO}_{3}$, the other tested bases did not show any advantage. Increasing the amount of base to 2.5 equivalents or elevating the temperature
Table 2: Selected bond lengths $[\AA]$ and angles $\left[{ }^{\circ}\right]$ for complexes Pd2.

\begin{tabular}{llll}
\multicolumn{3}{l}{ Bond lengths $(\AA)$} & Bond angles $\left(^{\circ}\right)$ \\
\hline $\mathrm{Pd}(1)-\mathrm{N}(2)$ & $2.036(3)$ & $\mathrm{N}(3)-\mathrm{Pd}(1)-\mathrm{N}(2)$ & $80.45(9)$ \\
$\mathrm{Pd}(1)-\mathrm{N}(3)$ & $2.038(2)$ & $\mathrm{N}(3)-\mathrm{Pd}(1)-\mathrm{Cl}(1)$ & $174.33(7)$ \\
$\mathrm{Pd}(1)-\mathrm{Cl}(2)$ & $2.2772(10)$ & $\mathrm{N}(3)-\mathrm{Pd}(1)-\mathrm{Cl}(2)$ & $94.80(6)$ \\
$\mathrm{Pd}(1)-\mathrm{Cl}(1)$ & $2.2938(9)$ & $\mathrm{N}(2)-\mathrm{Pd}(1)-\mathrm{Cl}(2)$ & $175.22(7)$ \\
$\mathrm{N}(2)-\mathrm{C}(2)$ & $1.373(4)$ & $\mathrm{N}(2)-\mathrm{Pd}(1)-\mathrm{Cl}(2)$ & $93.99(7)$ \\
$\mathrm{N}(2)-\mathrm{C}(41)$ & $1.327(4)$ & $\mathrm{Cl}(2)-\mathrm{Pd}(1)-\mathrm{Cl}(1)$ & $90.75(3)$ \\
$\mathrm{N}(3)-\mathrm{C}(3)$ & $1.304(3)$ & & \\
$\mathrm{N}(3)-\mathrm{C}(5)$ & $1.437(3)$ & &
\end{tabular}

to $140{ }^{\circ} \mathrm{C}$ could be an advantage for the reaction. Without any other screening, we finally determined the reaction conditions as following for the next substrates scope test: Pd2 (1 mol \%), toluene $/ \mathrm{H}_{2} \mathrm{O}(5: 1), 24 \mathrm{~h}, 140{ }^{\circ} \mathrm{C}$.

With the optimized reaction conditions, a standard reaction in a $5 \mathrm{mmol}$ scale between chlorobenzene and phenylboronic acid was carried out and $64 \%$ isolated yield was obtained (Table 4 , entry 1). Subsequently, different aryl chlorides and arylboronic acids were tested. The results were listed in Table 4. Aryl chlorides with an electron-withdrawing functional group, such as nitro (Table 4, entry 2), carbonyl (Table 4, entries 4-6), nitrile

Table 3: The optimization of conditions for Pd-catalyzed coupling reactions between chlorobenzene and phenylboronic acid ${ }^{\mathrm{a}}$.
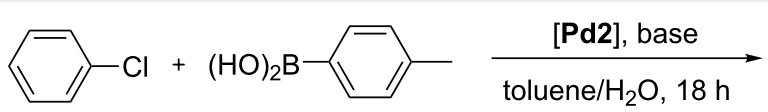

toluene/ $\mathrm{H}_{2} \mathrm{O}, 18 \mathrm{~h}$

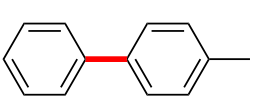

3-1

\begin{tabular}{|c|c|c|c|}
\hline Entry & Base (equiv) & Temperature $\left({ }^{\circ} \mathrm{C}\right)$ & Conversion. $(\%)^{\mathrm{b}}$ \\
\hline 1 & $\mathrm{~K}_{2} \mathrm{CO}_{3}(2.0)$ & 130 & 62 \\
\hline 2 & $\mathrm{Cs}_{2} \mathrm{CO}_{3}(2.0)$ & 130 & 31 \\
\hline 3 & $t$-BuOK $(2.0)$ & 130 & trace \\
\hline 4 & $\mathrm{NaOH}(2.0)$ & 130 & 16 \\
\hline 5 & DIPEA (2.0) & 130 & NR \\
\hline 6 & KOAc (2.0) & 130 & 8 \\
\hline 7 & $\mathrm{Na}_{2} \mathrm{CO}_{3}(2.0)$ & 130 & 22 \\
\hline 8 & $\mathrm{NaF}(2.0)$ & 130 & NR \\
\hline 9 & $\mathrm{NaOAc}(2.0)$ & 130 & NR \\
\hline 10 & EtONa (2.0) & 130 & 30 \\
\hline 11 & $\mathrm{~K}_{2} \mathrm{CO}_{3}(2.2)$ & 130 & 69 \\
\hline 12 & $\mathrm{~K}_{2} \mathrm{CO}_{3}(2.5)$ & 130 & 72 \\
\hline 13 & $\mathrm{~K}_{2} \mathrm{CO}_{3}(2.2)$ & 100 & 52 \\
\hline 14 & $\mathrm{~K}_{2} \mathrm{CO}_{3}(2.2)$ & 120 & 54 \\
\hline 15 & $\mathrm{~K}_{2} \mathrm{CO}_{3}(2.2)$ & 140 & 77 \\
\hline 16 & $\mathrm{~K}_{2} \mathrm{CO}_{3}(2.2)$ & 150 & 74 \\
\hline
\end{tabular}

aReaction conditions: chlorobenzene (1.0 mmol), 4-methylphenylboronic acid (1.2 mmol), toluene/ $\mathrm{H}_{2} \mathrm{O}(2.5 / 0.5, \mathrm{v} / \mathrm{v}), \mathbf{P d} 2(1 \mathrm{~mol} \%), 18 \mathrm{~h}, \mathrm{purged}$ with $\mathrm{N}_{2}$ for 2 min. ${ }^{b}$ Conversions were determined by GC. DIPEA = diisopropylethylamine. 
Table 4: Pd-catalyzed coupling between various aryl chlorides and arylboronic acids. ${ }^{\text {a }}$

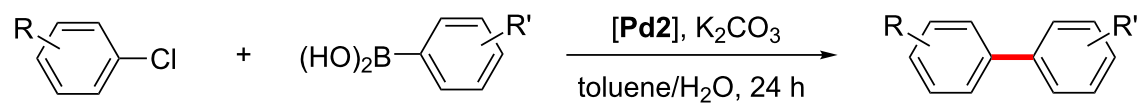

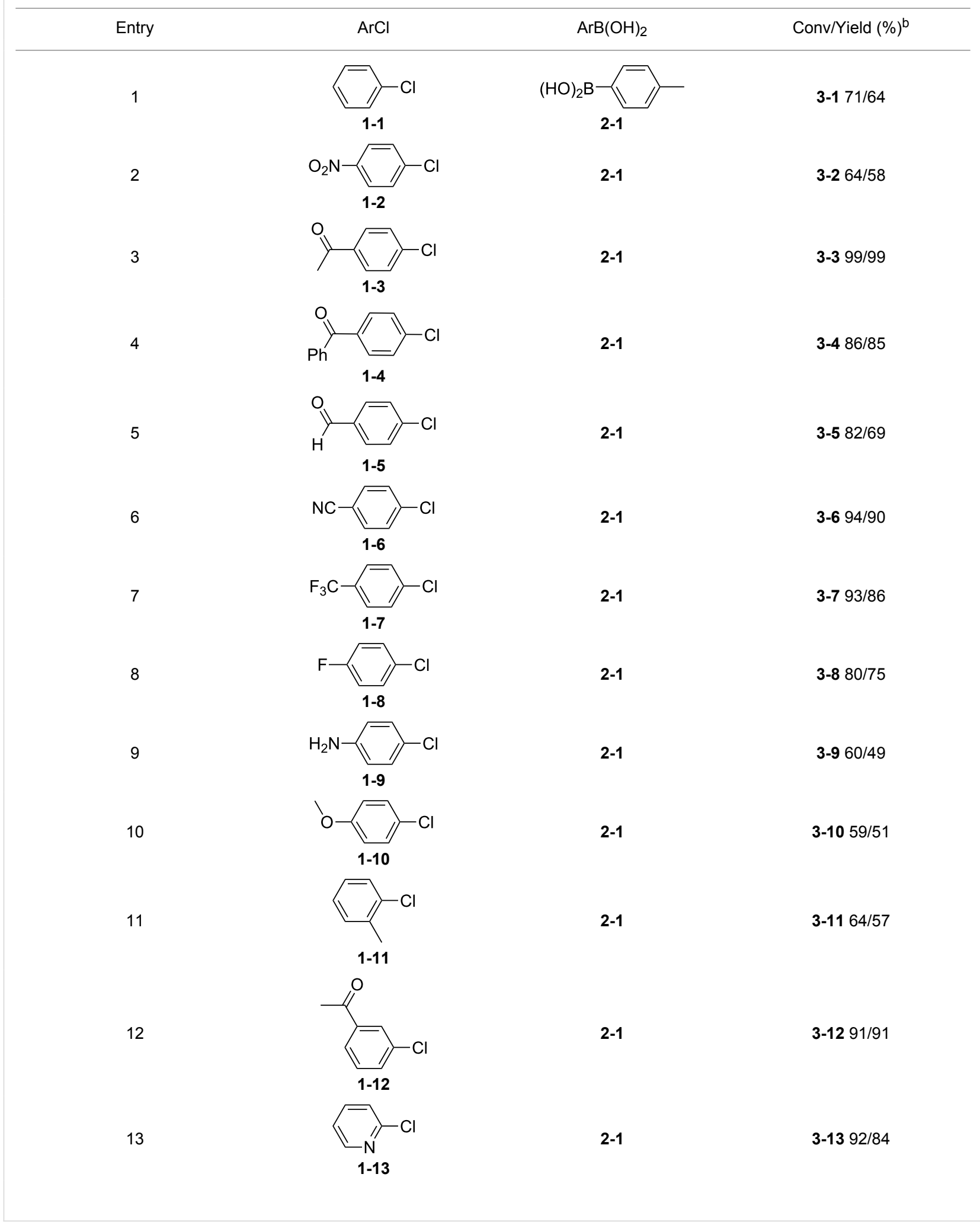


Table 4: Pd-catalyzed coupling between various aryl chlorides and arylboronic acids. ${ }^{\text {a }}$ (continued)

14

15

16

17
1-3

1-3

1-3

$1-3$
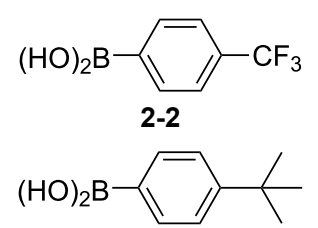

2-3<smiles>COc1ccc(BOO)cc1</smiles>

2-4

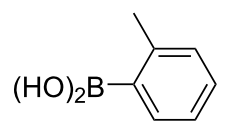

3-14 99/95

3-15 99/99

3-16 96/89

3-17 95/93

2-5

aReaction conditions: aryl chlorides $(5.0 \mathrm{mmol})$, arylboronic acid $(6.0 \mathrm{mmol}), \mathrm{K}_{2} \mathrm{CO}_{3}(11.0 \mathrm{mmol})$, toluene/ $\mathrm{H}_{2} \mathrm{O}(10 \mathrm{~mL} / 2 \mathrm{~mL}), \mathrm{Pd} 2(1 \mathrm{~mol} \%), 140{ }^{\circ} \mathrm{C}$, $24 \mathrm{~h}$, purged with $\mathrm{N}_{2}$ for 2 min. ${ }^{\mathrm{b}}$ Conversions were determined by $\mathrm{GC}$ and yields were isolated results.

and $\mathrm{CF}_{3}$ (Table 4, entries 6 and 7) could be coupled with 4-methylphenylboric acid in good to excellent yields. Aryl chlorides with an electron-donating functional group (Table 4, entries 9 and 10) and steric hindered 2-chlorotoluene (Table 4 , entry 11), which are usually regarded as reluctant substrates due to the sluggish oxidative addition of $\operatorname{Pd}(0)$ to aryl chlorides, proceeded successfully with moderate yields. Heterocyclic aryl chloride, for example, 2-chloropyridine, was also well tolerated and $84 \%$ isolated yields was obtained (Table 4 , entries 13 ). Different arylboronic acids were also examined to react with 4-chloroacetophenone in this system. No matter what kind of boronic acids were used: electron-deficient (Table 4, entry 14), electron-rich (Table 4, entries 15 and 16) or sterically hindered (Table 4, entry 17) arylboronic acids, high conversions and excellent isolated yields were achieved.

\section{Conclusion}

In summary, a series of geometrically-constrained iminopyridine-palladium complexes were prepared with various substituents. They promoted efficiently the Suzuki cross coupling of aryl chlorides. To result good catalytic activities the importance of bulkier groups at the imino moiety for the stabilization of the palladium species was sown. A variety of aryl chlorides and arylboronic acids were successfully coupled in high yields and selectivity.

\section{Experimental \\ General procedures}

All reactions were carried out under air atmosphere unless otherwise noted. All ${ }^{1} \mathrm{H}$ and ${ }^{13} \mathrm{C}$ NMR spectra were recorded on a Bruker AVANCE III $500 \mathrm{MHz}$ spectrometer in deuterated solvents with tetramethylsilane (TMS) as internal standard.
NMR multiplicities are abbreviated as follows: $\mathrm{s}=$ singlet, $\mathrm{d}=$ doublet, $\mathrm{t}=$ triplet, $\mathrm{q}=$ quartet, sept $=$ septet, $\mathrm{m}=$ multiplet, $\mathrm{br}=$ broad signal. Chemical shifts are given in $\mathrm{ppm}$ and are referenced to $\mathrm{SiMe}_{4}\left({ }^{1} \mathrm{H},{ }^{13} \mathrm{C}\right)$ and all spectra were obtained at $25{ }^{\circ} \mathrm{C}$ in the solvent indicated. Coupling constants $J$ are given in Hz. GC analyses were performed on Agilent 6890 instrument with FID detector using an HP-5 capillary column ( $30 \mathrm{~m} \times 0.32 \mathrm{~mm}$ (i.d.), $0.25 \mu$ ). High-resolution mass spectra were recorded in the EI mode on Agilent 6210 TOF mass spectrometry. Flash column chromatography was performed on neutral $\mathrm{SiO}_{2}$ (200-300 mesh) with ethyl acetate/petroleum as eluent. Melting points were determined on BÜCHI M-565 apparatus. X-ray crystallography were performed on a Bruker Smart Apex CCD area detector diffractometer using graphitemonochromated Mo K $\alpha$ radiation $(\lambda=0.71073 \AA)$. Details of the X-ray structure determinations and refinements are provided in Table 5. According to the synthetic procedures in the literature, the organic compounds $\mathbf{1 , 2}, \mathbf{3}$, and $\mathbf{4}$ were prepared in good yield $[69,71,75]$.

\section{Synthesis of $\mathbf{P d 2}$}

Toluene $(100 \mathrm{~mL})$ was added to a mixture of 6,7-dihydroquinolin-8(5H)-one (1.57 g, $11 \mathrm{mmol}), 2,6$-dibenzhydryl-4methylaniline $(5.27 \mathrm{~g}, 12 \mathrm{mmol}), \mathrm{PdCl}_{2}(1.77 \mathrm{~g}, 10 \mathrm{mmol})$ and $\mathrm{TsOH} \cdot \mathrm{H}_{2} \mathrm{O}(0.95 \mathrm{~g}, 5 \mathrm{mmol})$. After being degassed by $\mathrm{N}_{2}$ for $2 \mathrm{~min}$, the reaction mixture was sealed and stirred at $130{ }^{\circ} \mathrm{C}$ for 36 hours. Then the tube was allowed to cool to room temperature. After filtration and washing with toluene, the resulted residue was purified by column chromatography with dichloromethane as the eluent. The complex Pd2 was obtained as yellow solid (7.1 g, yield 95\%). Mp (dec.) $325{ }^{\circ} \mathrm{C} .{ }^{1} \mathrm{H}$ NMR $\left(\mathrm{CDCl}_{3}, 500 \mathrm{MHz}\right) \delta 9.42(\mathrm{t}, J=3.4 \mathrm{~Hz}, 1 \mathrm{H}), 7.70(\mathrm{~d}, J=3.4$ 
Table 5: Crystal data and structure refinement for $\mathbf{P d 2}$.

\begin{tabular}{|c|c|c|c|}
\hline Identification code & Pd2 & Identification code & Pd2 \\
\hline empirical formula & $\mathrm{C}_{42} \mathrm{H}_{34} \mathrm{~N}_{2} \mathrm{Cl}_{2} \mathrm{Pd} \cdot \mathrm{CH}_{2} \mathrm{Cl}_{2}$ & pcalcg $/ \mathrm{cm}^{3}$ & 1.4237 \\
\hline formula weight & 829.00 & $\mu / \mathrm{mm}^{-1}$ & 0.789 \\
\hline crystal system & orthorhombic & $F(000)$ & 3373.8 \\
\hline temperature/K & 173 & radiation & Mo Ka $(\lambda=0.71073)$ \\
\hline space group & Pbca & $2 \theta$ range for data collection $/{ }^{\circ}$ & 3.58 to 56.6 \\
\hline $\mathrm{a} / \AA$ & $18.996(3)$ & index ranges & $-24 \leq \mathrm{h} \leq 25,-26 \leq \mathrm{k} \leq 26,-27 \leq \mathrm{I} \leq 23$ \\
\hline $\mathrm{b} / \AA$ & $19.832(4)$ & reflections collected & 66946 \\
\hline $\mathrm{c} / \AA$ & $20.531(4)$ & independent reflections & $9585[$ Rint $=0.0438$, Rsigma $=0.0275]$ \\
\hline$\alpha /{ }^{\circ}$ & 90 & data/restraints/parameters & $9585 / 0 / 470$ \\
\hline$\beta / 0$ & 90 & goodness-of-fit on $\mathrm{F}^{2}$ & 1.123 \\
\hline $\mathrm{Y} / \mathrm{O}$ & 90 & final $R$ indexes $[I>=2 \sigma(I)]$ & $\mathrm{R} 1=0.0412, \mathrm{wR} 2=0.1026$ \\
\hline volume $/ \AA^{3}$ & $7735(2)$ & final $R$ indexes [all data] & $\mathrm{R} 1=0.0714, w R 2=0.1295$ \\
\hline Z & 8 & largest diff. peak/hole/e $\AA^{-3}$ & $1.09 /-0.68$ \\
\hline
\end{tabular}

$\mathrm{Hz}, 2 \mathrm{H}), 7.63(\mathrm{~m}, 16 \mathrm{H}), 7.30(\mathrm{~d}, J=7.4 \mathrm{~Hz}, 4 \mathrm{H}), 6.72(\mathrm{~s}, 2 \mathrm{H})$, $6.22(\mathrm{~s}, 2 \mathrm{H}), 2.14(\mathrm{~s}, 5 \mathrm{H}), 0.48(\mathrm{t}, J=6.5 \mathrm{~Hz}, 2 \mathrm{H}), 0.17(\mathrm{~m}$, $2 \mathrm{H}) ;{ }^{13} \mathrm{C} \mathrm{NMR}\left(\mathrm{CDCl}_{3}, 125 \mathrm{MHz}\right) \delta 182.1,151.9,149.9,143.2$, 142.4, 141.4, 140.3, 137.3, 137.0, 130.1, 129.9, 129.3, 129.0, 128.2, 127.0, 126.5, 53.6, 52.3, 31.6, 31.0, 27.6, 21.7, 19.8; HRMS (ESI+) $m / z:\left[\mathrm{M}-\mathrm{Cl}+\mathrm{CH}_{3} \mathrm{CN}\right]^{+}$calcd for $\mathrm{C}_{42} \mathrm{H}_{36} \mathrm{ClN}_{2} \mathrm{Pd} \cdot \mathrm{CH}_{3} \mathrm{CN}$, 750.1874; found, 750.1897.

\section{Synthesis of $\mathbf{P d} \mathbf{3}$}

Using xylene as the solvent, and following a similar procedure to that described for $\mathbf{P d 2}$ at $160{ }^{\circ} \mathrm{C}$, resulted $\mathbf{P d 3}$ with $29 \%$ yield as yellow powder. Mp $246{ }^{\circ} \mathrm{C} ;{ }^{1} \mathrm{H}$ NMR (DMSO- $d_{6}$, $500 \mathrm{MHz}) \delta 9.10(\mathrm{~d}, J=5.2 \mathrm{~Hz}, 1 \mathrm{H}), 8.22(\mathrm{~d}, J=7.8 \mathrm{~Hz}, 1 \mathrm{H})$, $7.87(\mathrm{~m}, 1 \mathrm{H}), 7.26(\mathrm{~m}, 1 \mathrm{H}), 7.14(\mathrm{~d}, J=7.7 \mathrm{~Hz}, 2 \mathrm{H}), 3.06(\mathrm{~m}$, $4 \mathrm{H}), 1.86(\mathrm{t}, J=6.1 \mathrm{~Hz}, 2 \mathrm{H}), 1.45(\mathrm{~d}, J=6.7 \mathrm{~Hz}, 6 \mathrm{H}), 1.26$ (d, $J=6.7 \mathrm{~Hz}, 6 \mathrm{H}), 0.89$ (s, 6H); ${ }^{13} \mathrm{C}$ NMR (DMSO- $\left.d_{6}, 125 \mathrm{MHz}\right)$ $\delta 181.7,153.4,150.2,142.5,140.7,140.5,139.6,128.4,128.3$, $123.4,42.5,37.7,29.3,29.0,27.4,25.7,24.8,24.5,23.7$; HRMS (ESI+) $m / z:\left[\mathrm{M}-\mathrm{Cl}+\mathrm{CH}_{3} \mathrm{CN}\right]^{+}$calcd for $\mathrm{C}_{23} \mathrm{H}_{30} \mathrm{ClN}{ }_{2} \mathrm{Pd} \cdot \mathrm{CH}_{3} \mathrm{CN}$, 518.1392; found, 518.1378.

\section{Synthesis of Pd4:}

Toluene $(4.0 \mathrm{~mL})$ was added to a mixture of 2-chloro-6,7-dihydroquinolin-8(5H)-one (181 mg, $1 \mathrm{mmol})$, 2,6-dibenzhydryl-4methylaniline (468 mg, $1.1 \mathrm{mmol}$ ), and $\mathrm{TsOH} \cdot \mathrm{H}_{2} \mathrm{O}(57 \mathrm{mg}$, $0.3 \mathrm{mmol}$ ). After degassed by $\mathrm{N}_{2}$ for $2 \mathrm{~min}$, the reaction mixture was sealed and stirred at $130{ }^{\circ} \mathrm{C}$ for 24 hours. Then the tube was allowed to cool to room temperature and $\mathrm{PdCl}_{2}(160 \mathrm{mg}$, $0.9 \mathrm{mmol}$ ) was added. After stirring at $50{ }^{\circ} \mathrm{C}$ for additional 24 hours, filtration and washing with toluene, the resulted residue was purified by column chromatography with dichloromethane as the eluent. The complex Pd4 was obtained as yellow solid (380 mg, yield 82\%). Mp (dec.) $306{ }^{\circ} \mathrm{C}$. Pd4 decomposes slowly when exposed open to air. ${ }^{1} \mathrm{H}$ NMR $\left(\mathrm{CDCl}_{3}, 500 \mathrm{MHz}\right) \delta 7.90(\mathrm{~d}, J=8.1 \mathrm{~Hz}, 1 \mathrm{H}), 7.69(\mathrm{~d}, J=8.1$ $\mathrm{Hz}, 1 \mathrm{H}), 7.34$ (d, $J=7.6 \mathrm{~Hz}, 1 \mathrm{H}), 7.20$ (d, $J=7.6 \mathrm{~Hz}, 2 \mathrm{H}), 3.13$ $(\mathrm{m}, 2 \mathrm{H}), 3.03(\mathrm{~m}, 2 \mathrm{H}), 2.44(\mathrm{~m}, 2 \mathrm{H}), 1.93(\mathrm{~m}, 2 \mathrm{H}), 1.44(\mathrm{~d}$, $J=6.7 \mathrm{~Hz}, 6 \mathrm{H}), 1.15(\mathrm{~d}, J=6.7 \mathrm{~Hz}, 6 \mathrm{H})$; HRMS (ESI+) $m / z$ : $\left[\mathrm{M}-\mathrm{Cl}+\mathrm{CH}_{3} \mathrm{CN}\right]^{+}$calcd for $\mathrm{C}_{21} \mathrm{H}_{25} \mathrm{Cl}_{2} \mathrm{~N}_{2} \mathrm{Pd} \cdot \mathrm{CH}_{3} \mathrm{CN}$, 524.0684; found, 524.0679.

\section{Synthesis of Pd5:}

In a similar procedure to that described for Pd2 with $81 \%$ yield as yellow powder. Mp (dec.) $282{ }^{\circ} \mathrm{C} ;{ }^{1} \mathrm{H}$ NMR (DMSO- $d_{6}$, $500 \mathrm{MHz}) \delta 8.05(\mathrm{~d}, J=7.8 \mathrm{~Hz}, 1 \mathrm{H}), 7.70(\mathrm{~d}, J=7.8 \mathrm{~Hz}, 1 \mathrm{H})$, $7.30(\mathrm{t}, J=8.1 \mathrm{~Hz}, 1 \mathrm{H}), 7.19(\mathrm{t}, J=8.1 \mathrm{~Hz}, 2 \mathrm{H}), 3.11(\mathrm{~m}, 2 \mathrm{H})$, $2.97(\mathrm{~d}, J=8.3 \mathrm{~Hz}, 5 \mathrm{H}), 2.40(\mathrm{t}, J=6.0 \mathrm{~Hz}, 2 \mathrm{H}), 1.82(\mathrm{t}, J=6.2$ $\mathrm{Hz}, 2 \mathrm{H}), 1.33$ (d, $J=6.9 \mathrm{~Hz}, 5 \mathrm{H}), 1.10$ (d, $J=6.8 \mathrm{~Hz}, 6 \mathrm{H})$; ${ }^{13} \mathrm{C}$ NMR (DMSO- $\left.d_{6}, 125 \mathrm{MHz}\right) \delta 163.8,151.6,141.2,140.9$, 140.2, 139.8, 132.1, 127.9, 123.4, 31.9, 27.9, 27.7, 27.2, 23.6, 23.5, 21.0; HRMS (ESI+) $m / z$ : $\left[\mathrm{M}-\mathrm{Cl}+\mathrm{CH}_{3} \mathrm{CN}\right]^{+}$calcd for $\mathrm{C}_{22} \mathrm{H}_{28} \mathrm{ClN}_{2} \mathrm{Pd} \cdot \mathrm{CH}_{3} \mathrm{CN}$, 504.1235; found, 504.1231.

\section{General procedure for Pd-catalyzed Suzuki cross-coupling reactions}

To a Young tube, aryl chlorides $(5.0 \mathrm{mmol}), \mathrm{K}_{2} \mathrm{CO}_{3}(1.5 \mathrm{~g}$, $11 \mathrm{mmol}$ ), arylboric acid (6 mmol), complex Pd2 (37.5 mg, $1 \mathrm{~mol} \%)$, toluene $(10 \mathrm{~mL})$ and $\mathrm{H}_{2} \mathrm{O}(2 \mathrm{~mL})$ were added. The mixture was degassed for $2 \mathrm{~min}$. Then, the sealed Young tube was set into the pre-heated $140{ }^{\circ} \mathrm{C}$ oil bath. After stirring for 24 hours, the Young tube was allowed to cool to room temperature. After filtration and extraction with toluene $(50 \mathrm{~mL})$, the resulted solution was concentrated under vacuum and the desired biaryl was isolated by column chromatography. 


\section{Supporting Information}

\section{Supporting Information File 1}

NMR spectra of palladium complexes and products. [http://www.beilstein-journals.org/bjoc/content/ supplementary/1860-5397-13-24-S1.pdf]

\section{Acknowledgements}

This work was supported by the National Natural Science Foundations of China (21473160, 21376224 and 21603190). Jin also thanks the support from Zhejiang University of Technology and Qianjiang Scholar Program funded by Zhejiang Province.

\section{References}

1. Negishi, E.-i. Handbook of organopalladium chemistry for organic synthesis; Wiley: New York Chichester, 2002.

2. Wu, X.-F.; Anbarasan, P.; Neumann, H.; Beller, M. Angew. Chem., Int. Ed. 2010, 49, 9047-9050. doi:10.1002/anie.201006374

3. Magano, J.; Dunetz, J. R. Chem. Rev. 2011, 111, 2177-2250. doi:10.1021/cr100346g

4. Budarin, V. L.; Shuttleworth, P. S.; Clark, J. H.; Luque, R. Curr. Org. Synth. 2010, 7, 614-627. doi:10.2174/157017910794328529

5. Farina, V. Adv. Synth. Catal. 2004, 346, 1553-1582. doi:10.1002/adsc.200404178

6. Engle, K. M.; Yu, J.-Q. J. Org. Chem. 2013, 78, 8927-8955. doi:10.1021/j0400159y

7. Li, H.; Johansson Seechurn, C. C. C.; Colacot, T. J. ACS Catal. 2012, 2, 1147-1164. doi:10.1021/cs300082f

8. Fleckenstein, C. A.; Plenio, H. Chem. Soc. Rev. 2010, 39, 694-711. doi:10.1039/B903646F

9. Elsevier, C. J.; Reedijk, J.; Walton, P. H.; Ward, M. D. Dalton Trans. 2003, 1869-1880. doi:10.1039/b303975g

10. Hanhan, M. E. Appl. Organomet. Chem. 2008, 22, 270-275. doi:10.1002/aoc.1389

11. Gildner, P. G.; Colacot, T. J. Organometallics 2015, 34, 5497-5508. doi:10.1021/acs.organomet.5b00567

12. Miura, M. Angew. Chem., Int. Ed. 2004, 43, 2201-2203. doi:10.1002/anie.200301753

13. Walker, S. D.; Barder, T. E.; Martinelli, J. R.; Buchwald, S. L. Angew. Chem., Int. Ed. 2004, 43, 1871-1876. doi:10.1002/anie.200353615

14. Wolfe, J. P.; Singer, R. A.; Yang, B. H.; Buchwald, S. L. J. Am. Chem. Soc. 1999, 121, 9550-9561. doi:10.1021/ja992130h

15. Martin, R.; Buchwald, S. L. Acc. Chem. Res. 2008, 41, 1461-1473. doi:10.1021/ar800036s

16. Kataoka, N.; Shelby, Q.; Stambuli, J. P.; Hartwig, J. F. J. Org. Chem. 2002, 67, 5553-5566. doi:10.1021/jo025732j

17. Hartwig, J. F. Synlett 2006, 1283-1294. doi:10.1055/s-2006-939728

18. Tang, H.; Menzel, K.; Fu, G. C. Angew. Chem., Int. Ed. 2003, 42, 5079-5082. doi:10.1002/anie.200352668

19. Hills, I. D.; Netherton, M. R.; Fu, G. C. Angew. Chem., Int. Ed. 2003, 42, 5749-5752. doi:10.1002/anie.200352858

20. Fu, G. C. Acc. Chem. Res. 2008, 41, 1555-1564. doi:10.1021/ar800148f
21. So, C. M.; Lau, C. P.; Kwong, F. Y. Org. Lett. 2007, 9, 2795-2798. doi:10.1021/ol070898y

22. Chung, K. H.; So, C. M.; Wong, S. M.; Luk, C. H.; Zhou, Z.; Lau, C. P.; Kwong, F. Y. Chem. Commun. 2012, 48, 1967-1969. doi:10.1039/c2cc15972d

23. Wong, S. M.; Yuen, O. Y.; Choy, P. Y.; Kwong, F. Y. Coord. Chem. Rev. 2015, 293-294, 158-186. doi:10.1016/j.ccr.2015.01.017

24. Tang, W.; Capacci, A. G.; Wei, X.; Li, W.; White, A.; Patel, N. D.; Savoie, J.; Gao, J. J.; Rodriguez, S.; Qu, B.; Haddad, N.; Lu, B. Z.; Krishnamurthy, D.; Yee, N. K.; Senanayake, C. H. Angew. Chem., Int. Ed. 2010, 49, 5879-5883. doi:10.1002/anie.201002404

25. Tang, W.; Keshipeddy, S.; Zhang, Y.; Wei, X.; Savoie, J.; Patel, N. D.; Yee, N. K.; Senanayake, C. H. Org. Lett. 2011, 13, 1366-1369. doi:10.1021/ol2000556

26. Li, C.; Xiao, G.; Zhao, Q.; Liu, H.; Wang, T.; Tang, W. Org. Chem. Front. 2014, 1, 225-229. doi:10.1039/c4qo00024b

27. Li, C.; Chen, T.; Li, B.; Xiao, G.; Tang, W. Angew. Chem., Int. Ed. 2015, 54, 3792-3796. doi:10.1002/anie.201411518

28. Lundgren, R. J.; Stradiotto, M. Chem. - Eur. J. 2012, 18, 9758-9769. doi:10.1002/chem.201201195

29. Herrmann, W. A.; Elison, M.; Fischer, J.; Köcher, C.; Artus, G. R. J. Angew. Chem., Int. Ed. Engl. 1995, 34, 2371-2374. doi:10.1002/anie.199523711

30. Herrmann, W. A.; Brossmer, C.; Öfele, K.; Reisinger, C.-P.; Priermeier, T.; Beller, M.; Fischer, H. Angew. Chem., Int. Ed. Engl. 1995, 34, 1844-1848. doi:10.1002/anie.199518441

31. Yan, X.; Liu, Y.; Xi, C. Appl. Organomet. Chem. 2008, 22, 341-345. doi:10.1002/aoc.1396

32. Alonso, D. A.; Nájera, C. Chem. Soc. Rev. 2010, 39, 2891-2902. doi:10.1039/b821314n

33. Hamasaka, G.; Sakurai, F.; Uozumi, Y. Chem. Commun. 2015, 51, 3886-3888. doi:10.1039/C4CC09726B

34. Moreno, I.; SanMartin, R.; Herrero, M. T.; Dominguez, E. Curr. Top. Catal. 2009, 8, 91-102.

35. Beletskaya, I. P.; Cheprakov, A. V. J. Organomet. Chem. 2004, 689, 4055-4082. doi:10.1016/j.jorganchem.2004.07.054

36. Bruneau, A.; Roche, M.; Alami, M.; Messaoudi, S. ACS Catal. 2015, 5 , 1386-1396. doi:10.1021/cs502011x

37. Chen, W.; Xi, C.; Wu, Y. J. Organomet. Chem. 2007, 692, 4381-4388. doi:10.1016/j.jorganchem.2007.07.006

38. Terrasson, V.; Prim, D.; Marrot, J. Eur. J. Inorg. Chem. 2008, 2008, 2739-2745. doi:10.1002/ejic.200800154

39. Nájera, C.; Gil-Moltó, J.; Karlström, S. Adv. Synth. Catal. 2004, 346, 1798-1811. doi:10.1002/adsc.200404195

40. Li, F.; Hor, T. S. A. Adv. Synth. Catal. 2008, 350, 2391-2400. doi:10.1002/adsc.200800356

41. Yu, J.; Wang, L.; Liu, M.; Qiu, J.; Shen, Q.; Fang, L.; Tang, J. Chin. J. Chem. 2012, 30, 1114-1118. doi:10.1002/cjoc.201100544

42. Saiyed, A. S.; Joshi, R. S.; Bedekar, A. V. J. Chem. Res. 2011, 35 , 408-411. doi:10.3184/174751911X13100589976564

43. Mukherjee, A.; Sarkar, A. Tetrahedron Lett. 2005, 46, 15-18. doi:10.1016/j.tetlet.2004.11.051

44. Silberg, J.; Schareina, T.; Kempe, R.; Wurst, K.; Buchmeiser, M. R. J. Organomet. Chem. 2001, 622, 6-18. doi:10.1016/S0022-328X(00)00783-X

45. Zhong, H.; Wang, J.; Li, L.; Wang, R. Dalton Trans. 2014, 43, 2098-2103. doi:10.1039/C3DT52970C 
46. Ishii, H.; Goyal, M.; Ueda, M.; Takeuchi, K.; Asai, M. Appl. Catal., A 2000, 201, 101-105. doi:10.1016/S0926-860X(00)00421-X

47. Park, S. B.; Alper, H. Org. Lett. 2003, 5, 3209-3212. doi:10.1021/ol030071d

48. Xiao, J.-C.; Twamley, B.; Shreeve, J. M. Org. Lett. 2004, 6 , 3845-3847. doi:10.1021/ol048327

49. Weng, C.-M.; Hong, F.-E. Dalton Trans. 2011, 40, 6458-6468. doi:10.1039/c1dt10233h

50. Chitanda, J. M.; Prokopchuk, D. E.; Quail, J. W.; Foley, S. R. Organometallics 2008, 27, 2337-2345. doi:10.1021/om800080e

51. Ceder, R. M.; Muller, G.; Ordinas, M.; Font-Bardia, M.; Solans, X. Dalton Trans. 2003, 3052-3059. doi:10.1039/B302375C

52. Paul, F.; Moulin, S.; Piechaczyk, O.; Le Floch, P.; Osborn, J. A. J. Am. Chem. Soc. 2007, 129, 7294-7304. doi:10.1021/ja068291k

53. Grasa, G. A.; Hillier, A. C.; Nolan, S. P. Org. Lett. 2001, 3, 1077-1080. doi:10.1021/ol015676t

54. Chen, W.; Xi, C.; Yang, K. Appl. Organomet. Chem. 2007, 21 , 641-644. doi:10.1002/aoc.1224

55. Bozic-Weber, B.; Constable, E. C.; Housecroft, C. E.; Neuburger, M.; Price, J. R. Dalton Trans. 2010, 39, 3585-3594. doi:10.1039/b925623g

56. Hotze, A. C. G.; Faiz, J. A.; Mourtzis, N.; Pascu, G. I.; Webber, P. R. A.; Clarkson, G. J.; Yannakopoulou, K.; Pikramenou, Z.; Hannon, M. J. Dalton Trans. 2006, 3025-3034. doi:10.1039/b518027a

57. Davies, D. L.; Lelj, F.; Lowe, M. P.; Ryder, K. S.; Singh, K.; Singh, S. Dalton Trans. 2014, 43, 4026-4039. doi:10.1039/c3dt52975d

58. Ouali, A.; Spindler, J.-F.; Jutand, A.; Taillefer, M. Adv. Synth. Catal. 2007, 349, 1906-1916. doi:10.1002/adsc.200600628

59. Huang, Y.-T.; Tang, X.; Yang, Y.; Shen, D.-S.; Tan, C.; Liu, F.-S. Appl. Organomet. Chem. 2012, 26, 701-706. doi:10.1002/aoc.2913

60. Huang, F.; Sun, Z.; Du, S.; Yue, E.; Ba, J.; Hu, X.; Liang, T.; Galland, G. B.; Sun, W.-H. Dalton Trans. 2015, 44, 14281-14292. doi:10.1039/C5DT01831E

61.Sun, W.-H.; Kong, S.; Chai, W.; Shiono, T.; Redshaw, C.; Hu, X.; Guo, C.; Hao, X. Appl. Catal., A: Gen. 2012, 447-448, 67-73. doi:10.1016/j.apcata.2012.09.011

62. Huang, F.; Xing, Q.; Liang, T.; Flisak, Z.; Ye, B.; Hu, X.; Yang, W.; Sun, W.-H. Dalton Trans. 2014, 43, 16818-16829. doi:10.1039/C4DT02102A

63. Huang, F.; Zhang, W.; Yue, E.; Liang, T.; Hu, X.; Sun, W.-H. Dalton Trans. 2016, 45, 657-666. doi:10.1039/C5DT03779D

64. Ye, B.; Wang, L.; Hu, X.; Redshaw, C.; Sun, W.-H. Inorg. Chim. Acta 2013, 407, 281-288. doi:10.1016/j.ica.2013.08.008

65. Grasa, G. A.; Singh, R.; Stevens, E. D.; Nolan, S. P. J. Organomet. Chem. 2003, 687, 269-279. doi:10.1016/S0022-328X(03)00375-9

66. John, L. C.; Gunay, A.; Wood, A. J.; Emmert, M. H. Tetrahedron 2013, 69, 5758-5764. doi:10.1016/j.tet.2013.03.011

67. Dai, S.; Sui, X.; Chen, C. Angew. Chem., Int. Ed. 2015, 54, 9948-9953. doi:10.1002/anie.201503708

68. Gholinejad, M.; Karimkhani, V.; Kim, I. Appl. Organomet. Chem. 2014, 28, 221-224. doi:10.1002/aoc.3110

69. Xie, Y.; Huang, H.; Mo, W.; Fan, X.; Shen, Z.; Shen, Z.; Sun, N.; Hu, B.; Hu, X. Tetrahedron: Asymmetry 2009, 20, 1425-1432. doi:10.1016/j.tetasy.2009.05.014

70. Chai, W.; Yu, J.; Wang, L.; Hu, X.; Redshaw, C.; Sun, W.-H. Inorg. Chim. Acta 2012, 385, 21-26. doi:10.1016/j.ica.2011.12.008

71. Ba, J.; Du, S.; Yue, E.; Hu, X.; Flisak, Z.; Sun, W.-H. RSC Adv. 2015, 5, 32720-32729. doi:10.1039/C5RA04722F
72. Tang, Y.; Zeng, Y.; Hu, Q.; Huang, F.; Jin, L.; Mo, W.; Sun, N.; Hu, B.; Shen, Z.; Hu, X.; Sun, W.-H. Adv. Synth. Catal. 2016, 358, 2642-2651. doi:10.1002/adsc.201600294

73. CCDC 1422920 contains the supplementary crystallographic data for this paper. These data can be obtained free of charge from The Cambridge Crystallographic Data Centre via http://www.ccdc.cam.ac.uk/data_request/cif.

74. Liu, L.; Zhang, S.; Chen, H.; Lv, Y.; Zhu, J.; Zhao, Y. Chem. - Asian J. 2013, 8, 2592-2595. doi:10.1002/asia.201300688

75. Yu, J.; Hu, X.; Zeng, Y.; Zhang, L.; Ni, C.; Hao, X.; Sun, W.-H. New J. Chem. 2011, 35, 178-183. doi:10.1039/C0NJ00516A

\section{License and Terms}

This is an Open Access article under the terms of the Creative Commons Attribution License

(http://creativecommons.org/licenses/by/4.0), which permits unrestricted use, distribution, and reproduction in any medium, provided the original work is properly cited.

The license is subject to the Beilstein Journal of Organic Chemistry terms and conditions: (http://www.beilstein-journals.org/bjoc)

The definitive version of this article is the electronic one which can be found at: doi:10.3762/bjoc. 13.24 